\title{
The Development of Macrophages from Large Mononuclear Cells in the Blood of Patients with Inflammatory Disease
}

\author{
David A. HoRwITZ with the technical assistance of \\ Robert V. Steagall, JR. \\ From the Department of Internal Medicine, the University of Texas \\ Southwestern Medical School, Dallas, Texas 75235, and the \\ Department of Internal Medicine, the University of Virginia \\ School of Medicine, Charlottesville, Virginia 22901
}

A B S T R A C T The origin and function of the increased numbers of "atypical lymphocytes" which appear in the blood of patients with many inflammatory diseases is not known. Leukocyte suspensions from eight patients with systemic lupus erythematosus (SLE), five patients with other rheumatic diseases, and five patients with infectious diseases were pulse-labeled with tritiated thymidine $\left(\mathrm{Tdr}^{-} \mathrm{H}\right)$ and sampled after 5 and $72 \mathrm{hr}$ in vitro. Radioautographs indicated that $35 \%$ of the total large, nonphagocytic mononuclear leukocytes incorporated $\mathrm{Tdr}-{ }^{3} \mathrm{H}$ during the initial $5 \mathrm{hr}$ of culture. $\mathrm{Tdr}-{ }^{8} \mathrm{H}-$ labeled large phagocytic or glass-adherent cells were observed only infrequently. After $72 \mathrm{hr}$ one-third of the original number of $\mathrm{Tdr}^{-}{ }^{3} \mathrm{H}$-labeled cells from patients with SLE developed the morphology of macrophages and the capacity to phagocytose latex particles. Similar findings were observed in patients with other rheumatic diseases and bacterial infections. In contrast, the thymidine-labeled cells from patients with infectious hepatitis and infectious mononucleosis were poorly viable in culture and rarely became macrophages. $\mathrm{Tdr}-{ }^{8} \mathrm{H}-$ labeled small lymphocytes were uncommon. The present experiments suggest that in patients with certain inflammatory diseases large, proliferating "lymphocytelike" cells are very immature monocyte precursors which appear in response to tissue injury. These DNA-

Dr. Horwitz is a recipient of a post-doctoral fellowship from the Arthritis Foundation. His present address is the Department of Internal Medicine, University of Virginia School of Medicine, Charlottesville, Virginia 22901.

This work has been presented in part at the Federation of American Societies for Experimental Biology, Atlantic City, N. J., 17 April 1970, and published in abstract form (1).

Received for publication 5 February 1971 and in revised form 9 November 1971. synthesizing cells together with mature monocytes may serve as the circulating source of macrophages.

\section{INTRODUCTION}

Although increased numbers of proliferating blood mononuclear leukocytes are found in a wide variety of inflammatory diseases, their origin and function are unknown. Using liquid scintillation counting methods, Horwitz, Stastny, and Ziff suggested that increased mononuclear uptake of tritiated thymidine $\left(\mathrm{Tdr}-{ }^{8} \mathrm{H}\right)^{1}$ occurred especially in the acute phase of an inflammatory disease and may reflect either a response to nonspecific tissue injury, or antigenic stimulation (2). Radioautographic studies were in agreement with other investigators who have shown that DNA-synthesizing cells are large mononuclear cells $(3,4)$ which have been called "atypical lymphocytes" (5).

In the present experiments the blood mononuclear leukocytes obtained from a group of patients with rheumatic and infectious diseases were labeled with $\mathrm{Tdr}-{ }^{3} \mathrm{H}$ in vitro and the cultures sampled at selected intervals to determine whether they acquired specific functional characteristics. The studies indicate that, although initially the labeled DNA-synthesizing cells are nonphagocytic cells, a significant percentage develop into macrophages within $72 \mathrm{hr}$.

\section{METHODS}

Classification of monomuclear leukocytes. Since tissue culture procedures alter the appearance of leukocytes, mononuclear cells were classified by size and phagocytic capacity

${ }^{1}$ Abbreviations used in this paper: JRA, juvenile rheumatoid arthritis; MEM, minimum essential medium; SLE, systemic lupus erythematosus; $\mathrm{Tdr}-{ }^{8} \mathrm{H}$, tritiated thymidine. 
rather than morphologic appearance. Three groups were described: (a) small, nonphagocytic $(<12 \mu)$; (b) large, phagocytic; and $(c)$ large, nonphagocytic. The small, nonphagocytic cells were small and medium lymphocytes which measured up to $12 \mu$ on gelatin-coated slides. The large, phagocytic cells could usually be recognized as monocytes at $5 \mathrm{hr}$, but after that time typical monocytes were not observed. The large nonphagocytic cells in the patients studied were pleomorphic varieties similar to the "atypical lymphocytes" reviewed by Wood and Frenkel (5). Macrophages in these studies were defined as mononuclear cells with intracytoplasmic polystyrene particles.

Patients. The diagnoses of the patients studied were systemic lupus erythematosus (SLE) ( 8 patients), rheumatoid arthritis, juvenile rheumatoid arthritis (JRA) (3 patients), rheumatic fever, acute sepsis, pneumococcal pneumonia, infectious hepatitis (2 patients), and infectious mononucleosis. The control individuals were five male and five female hospital employees who had normal erythrocyte sedimentation rates by the Westergren method.

Tissue culture procedure. 10 million washed blood leukocytes were cultured for $5 \mathrm{hr}$ using previously described techniques (2). The cells were suspended in minimal essential medium (MEM) for suspension cultures (Grand Island Biological Co., Grand Island, N. Y.), $15 \%$ type $\mathrm{AB}$ human serum (Hyland Laboratories, Los Angeles, Calif., Lot \#3188H001A1) and $1 \mu \mathrm{Ci} / \mathrm{ml}$ of $\mathrm{Tdr}^{-}{ }^{8} \mathrm{H}$ (New England Nuclear Corp., Boston, Mass., specific activity 0.067 $\mathrm{Ci} / m \mathrm{M})$ was added to each flask. The flasks were divided into two groups. To group 1, one drop of polystyrene particles (Bacto-Latex, 0.81 $\mu$, Difco Laboratories, Detroit, Mich.) was added and the cells incubated at $37^{\circ} \mathrm{C}$ in $5 \%$ $\mathrm{CO}_{2}$ and air for $5 \mathrm{hr}$. The cells were washed three times $(100 \mathrm{~g})$, suspended in a drop of serum and smeared onto gelatin-coated slides with a red sable brush.

Group 2 cells were similarly incubated for $5 \mathrm{hr}$ with $\mathrm{Tdr}-{ }^{3} \mathrm{H}$, centrifuged at $100 \mathrm{~g}$ for $10 \mathrm{~min}$, and washed with MEM. The cells were placed in new flasks with fresh medium, and $15 \%$ serum, and incubated for an additional 67 hr. Cold thymidine $10^{-4} \mathrm{M}$ was added to inhibit further cell division (6) and minimize reutilization. $5 \mathrm{hr}$ before termination polystyrene particles were added. At the conclusion of the culture period the cells were counted with a hemocytometer, washed three times $(100 \mathrm{~g})$ and smeared onto gelatin-coated slides. The slides were air dried and fixed in cold methanol $15 \mathrm{~min}$ for later radioautography.

Cell counts and trypan blue viability studies obtained at $72 \mathrm{hr}$ indicated that approximately one-half of the mononuclear cells remained. After this time the number of viable cells decreased rapidly. The number of each cell type at 5 and $72 \mathrm{hr}$ was calculated by multiplying the number per culture by the per cent of that cell type determined from a 1000 cell differential count.

Other cultures were prepared in modified Sykes-Moore chambers (Bellco Glass, Inc., Vineland, N. J.) containing glass cover slips $25 \mathrm{~mm}$ in diameter. In these experiments 10 million leukocytes were suspended in $2 \mathrm{ml}$ Medium 199 (Grand Island Biological Co.), 30\% fetal calf serum (Microbiological Associates, Inc., Bethesda, Md.) and $\mathrm{Tdr}-{ }^{8} \mathrm{H}$. After a $3 \mathrm{hr}$ incubation, the leukocytes were separated into glass adherent and nonadherent populations. To obtain adherent cells, the cover slips were washed three times with $2 \mathrm{ml}$ of Medium 199 by vigorous shaking and mounted on glass slides with Permount (Fisher Scientific Co., Pittsburgh, $\mathrm{Pa}$.). Quantitation by cell density indicated that about $10 \%$ of the original number of cells were glass adherent and consisted of monocytes and granulocytes (mean number of monocytes 59\%, range 31-64\%). The nonadherent cells, consisting of the culture supernatant and pooled cover slip washes, were washed three times and smeared onto gelatin-coated slides. Each preparation was fixed in cold methanol before radioautography.

Radioautography. Radioautographs were prepared and stained as described previously (2). The 5- and 72-hr smears of each patient were dipped simultaneously and a minimum of 1000 cells were counted. To be scored as a labeled cell at least 10 grains over the nucleus were present. The background grain count was always less than 200 grains per oil immersion field.

\section{RESULTS}

Morphology of $\mathrm{Tdr}^{3} \mathrm{H}$-labeled mononuclear leukocytes. The features of mononuclear leukocytes which incorporated $\mathrm{Tdr}-{ }^{3} \mathrm{H}$ during the initial $5 \mathrm{hr}$ and other labeled cells cultured for $72 \mathrm{hr}$ are described in the legend accompanying Fig. 1. Typically, DNA-synthesizing cells at $5 \mathrm{hr}$ were large, nonphagocytic cells with mature nuclei without nucleoli. Monocytes with intracytoplasmic latex particles were not $\mathrm{Tdr}-{ }^{3} \mathrm{H}$ labeled. During the 3 day culture period, labeled cells became larger and some nuclei were compressed by an increased amount of pale staining, vacuolated cytoplasm that now contained numerous latex particles. These cells had become macrophages. Other large labeled cells with basophilic cytoplasm were also present, but $\mathrm{Tdr}-{ }^{3} \mathrm{H}-$ labeled small lymphocytes were rarely observed. Occasionally, large blast-like cells 20 to $30 \mu$ with immature nuclei and abundant basophilic cytoplasm were observed. These appeared to be "transformed" small lymphocytes and were not $\mathrm{Tdr}-{ }^{3} \mathrm{H}$ labeled.

Minimal cell division occurred in vitro. The mean grain counts of the 5- and 72-hr cell smears of each patient dipped simultaneously were 27 and 19 grains, indicating a mean of less than one cell division.

Phagocytic capacity of $T d r-{ }^{3} H$-labeled cells. In agreement with previous studies (2-4) only $0.1 \%$ of the blood mononuclear leukocytes from five normal individuals incorporated $\mathrm{Tdr}-{ }^{3} \mathrm{H}$ after $5 \mathrm{hr}$ of incubation. Table I shows that after $5 \mathrm{hr}$ all patients with inflammatory diseases demonstrated increased numbers of DNAsynthesizing cells (range $0.7-17.0 \%$ ). Only 4 of 18 patients demonstrated $\mathrm{Tdr}-{ }^{8} \mathrm{H}$-labeled phagocytes and these were present in small numbers. In sharp contrast, at $72 \mathrm{hr} \mathrm{Tdr}-{ }^{3} \mathrm{H}$-labeled phagocytes were observed in 17 of 18 patients, and in 12 at least one-half of the remaining labeled leukocytes had developed the capacity to phagocytose latex particles.

The table also indicates that the viability of labeled cells correlated well with the number of labeled macrophages observed. One-half of the original number of tritium-labeled cells were recovered at $72 \mathrm{hr}$ from the SLE group and two-thirds of these became phagocytes. 


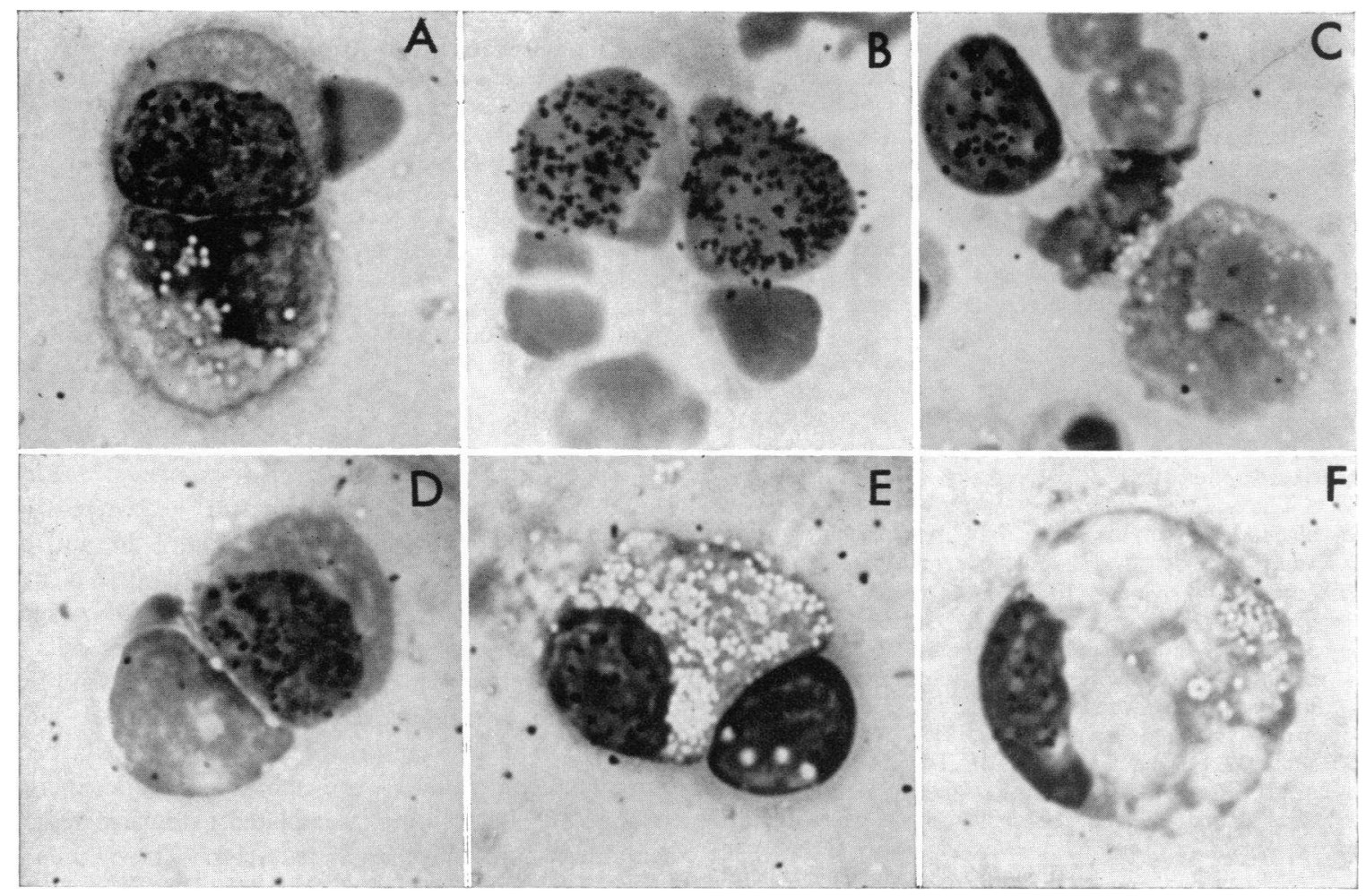

Figure 1 Photomicrographs of Leishman-Giemsa-stained $\mathrm{Tdr}-{ }^{3} \mathrm{H}$-labeled mononuclear leukocytes at 5 and $72 \mathrm{hr}$. A through $\mathrm{C}$ are 5 -hr labeled cells. (A) $\mathrm{Tdr}-{ }^{3} \mathrm{H}$-labeled "lymphocytelike" cell $16 \mu$ in diameter. The nucleus is notched and eccentric with loosely clumped chromatin. Nucleoli are not present. There is an abundant amount of bluish-gray finely granular cytoplasm. Note the smooth cell margin. Next to this cell is a monocyte with intracytoplasmic latex particles and a ruffled cell membrane. (G. W.-SLE, $\times 1540)$. (B) Two labeled cells have scanty, moderately basophilic cytoplasm. (B. C.-infectious hepatitis, $\times 1540$ ). $\mathrm{Tdr}-{ }^{8} \mathrm{H}-$ labeled cells with strongly basophilic cytoplasm were occasionally observed in hepatitis and other diseases studied. (C) An example of a small labeled mononuclear cell. The cell (11 $\mu$ ) has a round nucleus with dense masses of chromatin and a thin rim of basophilic cytoplasm. (G. W.-SLE, $\times 1540$ ). Small $\mathrm{Tdr}^{3} \mathrm{H}$-labeled cells were rarely observed at 5 or $72 \mathrm{hr}$. Degenerating, bare $\mathrm{Tdr}-{ }^{3} \mathrm{H}$-labeled nuclei were common at $72 \mathrm{hr}$. D through $\mathrm{F}$ show $5 \mathrm{hr}$ pulse-labeled cells cultured for $72 \mathrm{hr}$. (D) A $\mathrm{Tdr}-{ }^{3} \mathrm{H}$-labeled nonphagocytic cell. In this category were large cells similar to macrophages except that no latex particles were present; large cells with features suggesting plasma cells, such as eccentric nuclei and basophilic cytoplasm (seen especially in infectious hepatitis); and occasionally cells with centrally placed nuclei and basophilic cytoplasm. The cell shown contains an abundant basophilic cytoplasm (G. W.-SLE, $\times 1540$. (E) and (F) $\mathrm{Tdr}-{ }^{8} \mathrm{H}$-labeled macrophages. These cells have increased in size and are 21 and $23 \mu$. The nuclei are irregular and in $F$ is compressed by the abundant, slightly basophilic, vacuolated cytoplasm. The cell margins acquired a ruffled appearance. Note the numerous latex particles in the cytoplasm. (G. W. - SLE, $\times 1540$ ).

In this group, then, one-third of the original number of $\mathrm{Tdr}^{-}{ }^{\mathrm{S}} \mathrm{H}-$ labeled cells had become macrophages. In a miscellaneous group whose diagnoses were rheumatoid arthritis, JRA,, septicemia, and pneumonia, 30\% of the original number of $\mathrm{Tdr}-{ }^{3} \mathrm{H}$-labeled cells were recovered and one-half of these became macrophages. In contrast, the DNA-synthesizing cells from two patients with infectious hepatitis and one with infectious mononucleosis were poorly viable in culture $(12,8$, and
$3 \%$ remaining), and of these only 6 of 44 were phagocytic. In these patients less than $1 \%$ of the original number of $\mathrm{Tdr}-{ }^{8} \mathrm{H}$-labeled cells became macrophages.

The steady rise in $\mathrm{Tdr}-{ }^{-} \mathrm{H}$-labeled macrophages at 24 and $72 \mathrm{hr}$ in a patient with SLE is illustrated in Fig. 2. During this time the total number of labeled cells declined to $40 \%$ of the original population.

Comparison of Tdr- ${ }^{3} \mathrm{H}$-labeled to the unlabeled mononuclear cells in vitro. The relationship of the $\mathrm{Tdr}-{ }^{8} \mathrm{H}-$ 


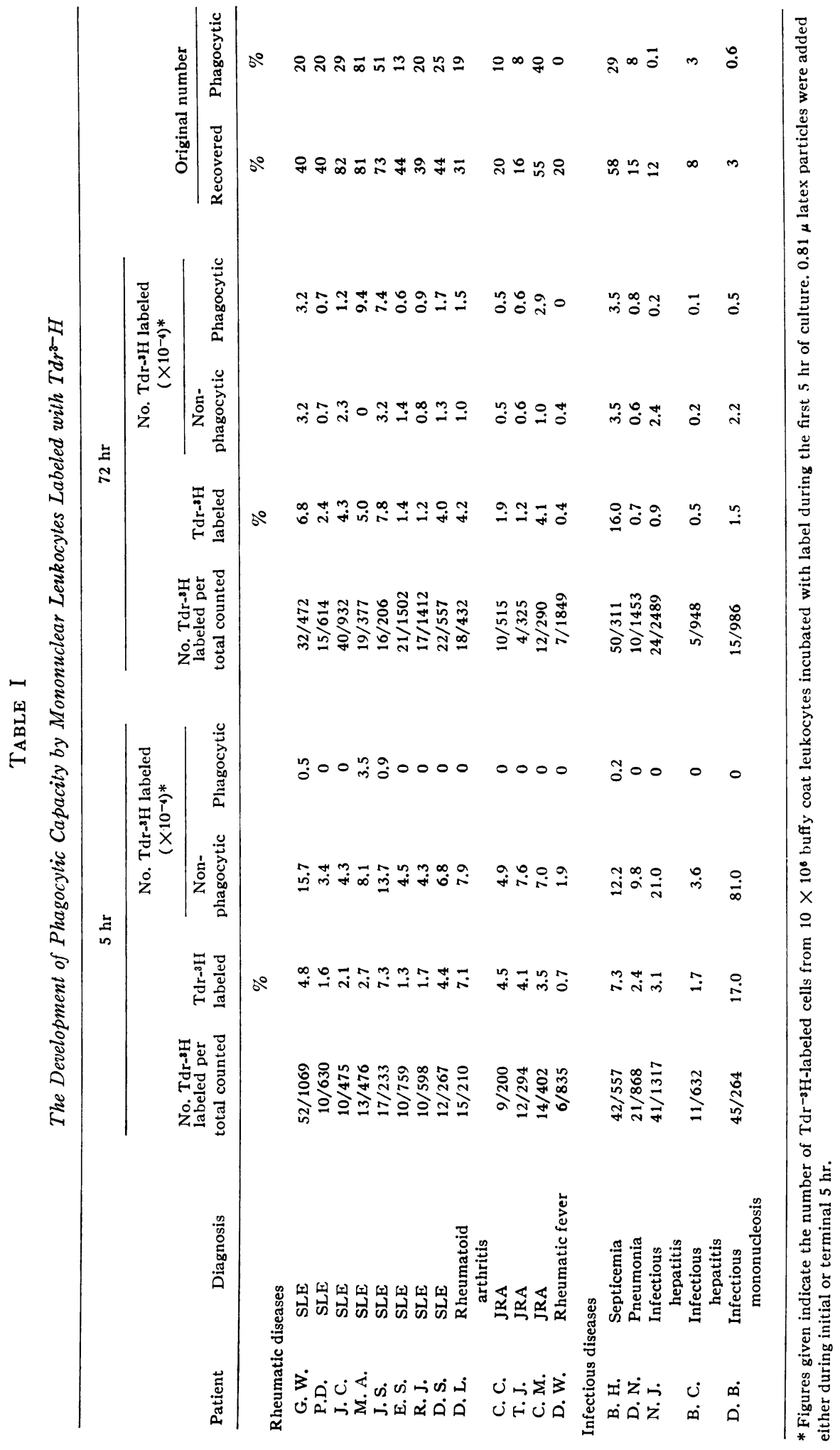




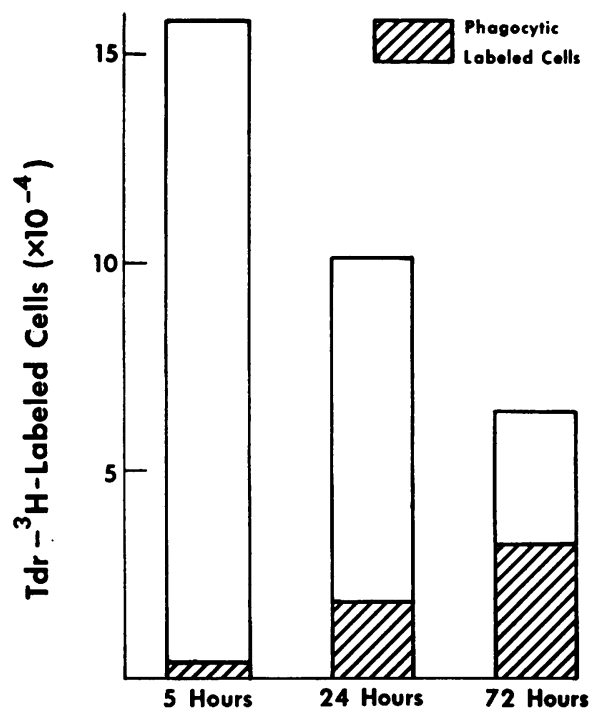

Figure 2 The development of $\mathrm{Tdr}-{ }^{3} \mathrm{H}$-labeled macrophages in vitro. Patient G. W.-SLE.

labeled cells with the total populations of mononuclear cells at 5 and $72 \mathrm{hr}$ is shown in Fig. 3. At $5 \mathrm{hr}$ the large nonphagocytic cells comprised $14 \%$ and the large phagocytic cells $20 \%$ of the mononuclear cells observed. Not shown are the small lymphocytes which accounted for $66 \%$ of the mononuclears. With rare exceptions, the $\mathrm{Tdr}^{-}{ }^{3} \mathrm{H}$-labeled cells appeared only in the large nonphagocytic population where they comprised 35\% of these cells. At $72 \mathrm{hr}$ one-half of the lymphocytes remained, but significantly fewer large mononuclear cells survived. Only one-fifth of the original number of large phagocytic cells were recovered. Nonetheless, after 3
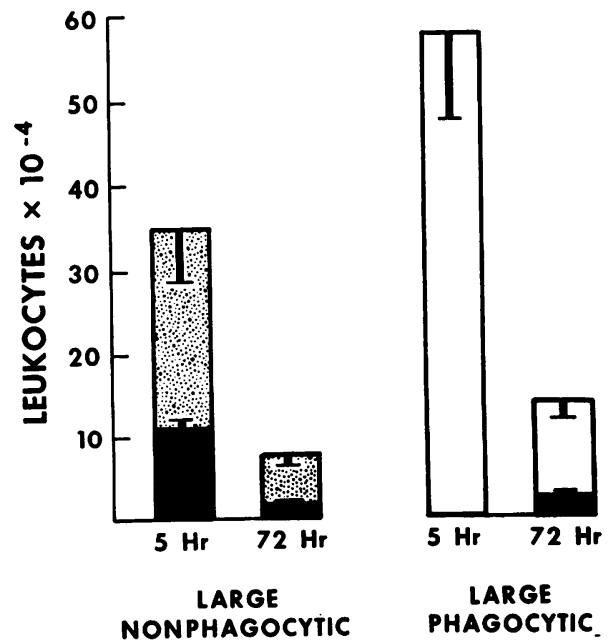

Figure $3 \mathrm{Tdr}-{ }^{8} \mathrm{H}$-labeled mononuclear populations after 5 and $72 \mathrm{hr}$ in vitro compared with their corresponding unlabeled populations. The bar indicates the mean value of all patients studied and the SE of each group is shown. days $59 \%$ of the $\mathrm{Tdr}-{ }^{3} \mathrm{H}$-labeled cells observed contained latex particles and comprised $14 \%$ of the remaining macrophages. The $\mathrm{Tdr}-{ }^{8} \mathrm{H}-$ labeled cells survived as well as their original large nonphagocytic population (27\% and $24 \%$, respectively).

Glass-adherent and nonadherent $T d r-^{3} H$-labeled cells. The following studies were performed to learn if human $\mathrm{Tdr}-{ }^{8} \mathrm{H}$-labeled macrophage precursors stick to glass, a property of the recently described mouse marrow promonocyte (7). Blood leukocytes were cultured on glass coverslips and separated into adherent and nonadherent populations. Table II indicates that practically all the $\mathrm{Tdr}-{ }^{-} \mathrm{H}-$ labeled cells were found in the nonadherent fraction. Although the concentration of blood monocytes increased 10-fold on the coverslip preparations, adherent $\mathrm{Tdr}-{ }^{3} \mathrm{H}$-labeled cells from three patients with SLE and one with pneumonia were observed only rarely. A tritium-labeled adherent cell is shown in Fig. 4 which according to recent criteria (8) is a promonocyte.

Comparison of the $T d r^{3} \mathrm{H}$-labeled with the unlabeled mononuclear lenkocytes in vivo. Using the described criteria for classifying mononuclear cells by size and phagocytic capacity, the number of mononuclear leukocytes of the blood of 10 normal individuals was determined. The mean number of large phagocytic cells $\left(400 / \mathrm{mm}^{3}\right)$ was consistent with Wintrobe's (9) mean value of monocytes $\left(500 / \mathrm{mm}^{3}\right)$. The values determined for lymphocytes and granulocytes were also similar to those given by Wintrobe and indicate that the leukocyte counts determined in vitro appear to reflect the number of circulating small lymphocytes, large "lymphocytes," and monocytes (Table III).

Increased numbers of large nonphagocytic cells $(P$ $<0.005)$ and decreased numbers of small lymphocytes $(P<0.05)$ were found in the patients studied when compared with normal individuals (Table III). There was no significant difference in the number of monocytes or the total mononuclear cells between the two groups. Since $35 \%$ of the large nonphagocytic mono-

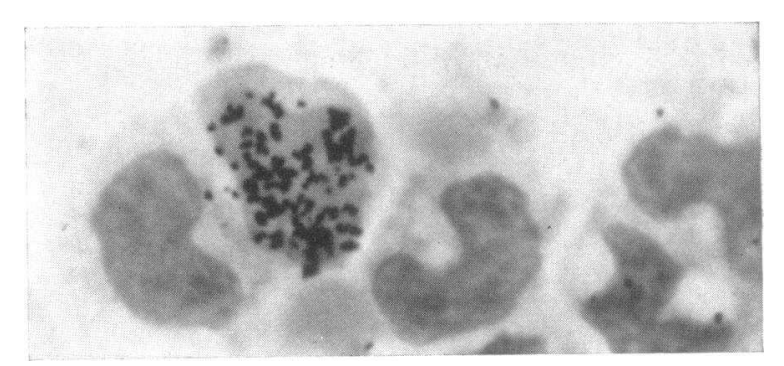

Figure $4 \mathrm{Tdr}-{ }^{8} \mathrm{H}$-labeled glass-adherent leukocyte. The labeled cell $(14 \mu)$ has an irregular. notched nucleus and moderately basophilic cytoplasm. Adjacent to the labeled cell are two monocytes. (H. M.-SLE, $\times 1540$ ). 
TABLE II

Separation of DNA-Synthesizing Leukocytes into Glass-Adherent and Nonadherent Populations

\begin{tabular}{llcccc}
\hline Patient & \multicolumn{1}{c}{ Diagnosis } & $\begin{array}{c}\text { Nonadherent Tdr-sH labeled per } \\
\text { total large mononuclears }\end{array}$ & $\begin{array}{c}\text { Nonadherent } \\
\text { Tdr-2H labeled }\end{array}$ & $\begin{array}{c}\text { Adherent Tdr-lH labeled per } \\
\text { total large mononuclears }\end{array}$ & $\begin{array}{c}\text { Adherent } \\
\text { Tdr-SH labeled }\end{array}$ \\
\hline & & & $\%$ & & $\%$ \\
H. M. & SLE & $26 / 208$ & 12.5 & $4 / 659$ & 0.6 \\
J. C. & SLE & $19 / 214$ & 10.5 & $1 / 851$ & 0.1 \\
R. F. & SLE & $20 / 75$ & 24.0 & $1 / 799$ & 0.1 \\
A. S. & Pneumoccal pneumonia & $14 / 131$ & 10.7 & $0 / 788$ & 0 \\
\hline
\end{tabular}

nuclear cells could be labeled with $\mathrm{Tdr}-{ }^{3} \mathrm{H}$ and many of these later became macrophages in vitro, many of these cells may function as proliferating macrophages in the inflammatory lesions of the patients studied. These shifts in the blood mononuclear populations are schematically shown in Fig. 5.

\section{DISCUSSION}

To avoid the pitfalls of some previous studies dealing with the relationship between lymphocytes, monocytes, and macrophages, blood mononuclear cells were classified by size and phagocytic capacity rather than by morphologic features, and reported in terms of absolute numbers rather than percentage observed. A threefold increase in the number of large, nonphagocytic, blood mononuclear leukocytes was found in patients with inflammatory diseases. Many of these were morphologically similar to the "stress lymphocytes" of Frank and Dougherty (10), and as a group to the "atypical lymphocytes" of Wood and Frenkel (5). 35\% of these large nonphagocytic mononuclears were DNAsynthesizing cells similar to those originally described by Bond and coworkers (3) and recently by Horwitz, Stastny, and Ziff (2). $\mathrm{Tdr}-{ }^{8} \mathrm{H}$-labeled large phagocytic cells (monocytes) or small lymphocytes were rare.

The DNA-synthesizing "atypical lymphocytes" could be divided into two populations which differed in viability and capacity to become phagocytes after $72 \mathrm{hr}$ of culture. The $\mathrm{Tdr}-{ }^{8} \mathrm{H}-$ labeled cells in patients with infectious hepatitis and infectious mononucleosis were poorly viable in culture and rarely became macrophages. The results in infectious mononucleosis are consistent with those of $\mathrm{Hirsch}^{2}$ and MacKinney (11). The origin and function of these cells are unknown.

In patients with SLE, one-half of the Tdr- ${ }^{8} \mathrm{H}$-labeled cells were recovered at $72 \mathrm{hr}$ and two-thirds of these became phagocytes. Similarly, patients with rheumatoid arthritis and others with bacterial infections demonstrated large numbers of macrophage precursors. The site of origin of these cells may be the bone marrow. There

${ }^{2}$ Hirsch, J. G. Unpublished observation. is conclusive evidence the macrophages which appear in inflammatory lesions are hematogenous and derived from rapidly dividing precursors in the bone marrow (12-16). The circulating antecedent of these macrophages is considered to be the monocyte $(7,14,15)$. Human DNA-synthesizing macrophage precursors may be derived from the monocyte cell line. They may be mature monocytes that have been induced to proliferate before sampling and lack the morphologic and physiological properties of this cell consequent to DNA synthesis.

Secondly, these large mononuclear cells may be the human equivalent to the mouse promonocyte. Van Furth and Cohen (15) and van Furth, Hirsch, and Fedorko (17) have recently described the marrow precursors of mouse monocytes which they called promonocytes. Both "atypical" mononuclear cells and promonocytes can incorporate $\mathrm{Tdr}-{ }^{3} \mathrm{H}$ and later become mature macrophages. However, mouse promonocytes by definition stick to glass and phagocytose staphylo-

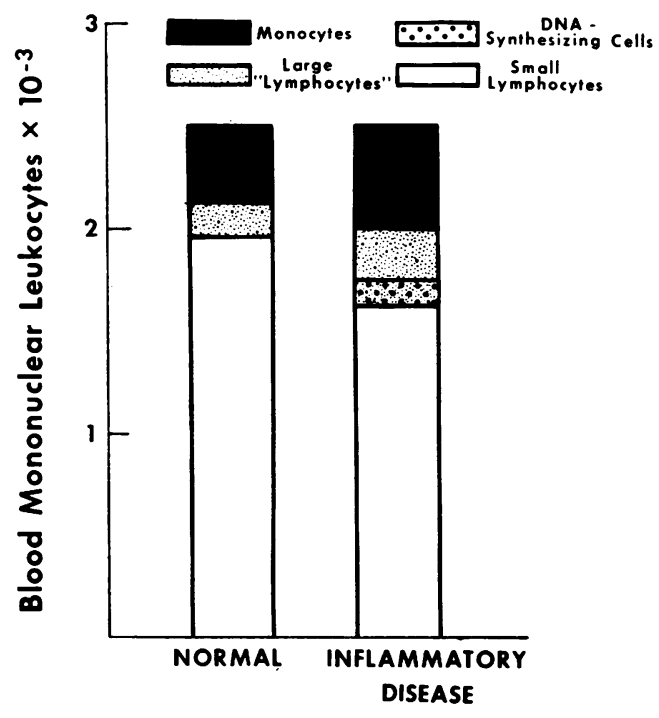

FIGURE 5 Blood mononuclear leukocyte populations in the normal steady state and in inflammatory disease. 
TABLE III

Blood Leukocyte Concentration Values in Patients with Inflammatory Diseases Compared with Normal Individuals $\left(\times 10^{-3} / \mathrm{mm}^{3}\right)$

\begin{tabular}{|c|c|c|c|c|c|c|}
\hline \multirow[b]{2}{*}{ Individual } & \multicolumn{4}{|c|}{ Mononuclear leukocytes } & \multirow[b]{2}{*}{ Granulocytes } & \multirow[b]{2}{*}{$\begin{array}{c}\text { Total } \\
\text { leukocytes }\end{array}$} \\
\hline & Small & $\begin{array}{l}\text { Large non- } \\
\text { phagocytic }\end{array}$ & $\begin{array}{c}\text { Large } \\
\text { phagocytic }\end{array}$ & Total & & \\
\hline \multicolumn{7}{|c|}{ Normal individuals } \\
\hline \multicolumn{7}{|c|}{ A. Subjects studied } \\
\hline W. J. & 2.20 & 0.12 & 0.58 & 2.9 & 4.9 & 7.8 \\
\hline D. D. & 1.47 & 0.10 & 0.33 & 1.9 & 5.1 & 7.0 \\
\hline B. $\mathrm{R}$. & 1.52 & 0.04 & 0.44 & 2.0 & 5.0 & 7.4 \\
\hline $\begin{array}{l}\text { W. M. } \\
\text { L. D. }\end{array}$ & $\begin{array}{l}1.93 \\
2.49\end{array}$ & $\begin{array}{l}0.08 \\
0.22\end{array}$ & $\begin{array}{l}0.39 \\
0.49\end{array}$ & $\begin{array}{l}2.4 \\
3.2\end{array}$ & $\begin{array}{l}4.6 \\
6.3\end{array}$ & $\begin{array}{l}7.0 \\
9.5\end{array}$ \\
\hline M. B. & 2.34 & 0.18 & 0.38 & 2.9 & 6.1 & 9.0 \\
\hline N. 0 . & 2.26 & 0.09 & 0.45 & 2.8 & 5.6 & 8.4 \\
\hline B. 0 . & 1.13 & 0.09 & 0.38 & 1.6 & 3.6 & 5.2 \\
\hline C. M. & 2.57 & 0.10 & 0.23 & 2.9 & 4.7 & 7.6 \\
\hline E. S. & 2.23 & 0.09 & 0.38 & 2.7 & 5.1 & 7.8 \\
\hline Mean & 2.02 & 0.11 & 0.41 & 2.5 & 5.1 & 7.7 \\
\hline Range & $(1.13-2.57)$ & $(0.04-0.22)$ & $(0.23-0.58)$ & $(1.6-3.2)$ & $(3.6-6.3)$ & $(5.2-9.5)$ \\
\hline \multicolumn{7}{|c|}{ Patients with inflammatory diseases } \\
\hline \multicolumn{7}{|c|}{ A. Rheumatic diseases } \\
\hline G. W. & 1.15 & 0.26 & 0.39 & 1.8 & 3.0 & 4.8 \\
\hline $\begin{array}{l}\text { P. D. } \\
\text { J. C. }\end{array}$ & $\begin{array}{l}1.10 \\
0.96\end{array}$ & $\begin{array}{l}0.30 \\
0.10\end{array}$ & $\begin{array}{l}0.30 \\
0.44\end{array}$ & $\begin{array}{l}1.7 \\
1.5\end{array}$ & $\begin{array}{l}5.2 \\
4.9\end{array}$ & $\begin{array}{l}6.9 \\
6.4\end{array}$ \\
\hline M. A. & 1.56 & 0.14 & 0.33 & 2.0 & 2.3 & 4.3 \\
\hline J.S. & 0.77 & 0.17 & 0.22 & 1.2 & 3.6 & 4.8 \\
\hline $\begin{array}{l}\text { E. S. } \\
\text { R. J. }\end{array}$ & $\begin{array}{l}1.87 \\
1.01\end{array}$ & $\begin{array}{l}0.08 \\
0.16\end{array}$ & $\begin{array}{l}0.23 \\
0.39\end{array}$ & $\begin{array}{l}2.2 \\
1.6\end{array}$ & $\begin{array}{l}3.0 \\
4.0\end{array}$ & $\begin{array}{l}5.2 \\
5.6\end{array}$ \\
\hline D. S. & 0.81 & 0.46 & 0.20 & 1.5 & 7.3 & 8.8 \\
\hline D. L. & 0.53 & 0.22 & 0.45 & 1.2 & 8.9 & 10.1 \\
\hline C. C. & 0.21 & 0.06 & 0.23 & 0.5 & 5.3 & 5.8 \\
\hline T. J. & 1.12 & 0.14 & 0.44 & 1.7 & 7.2 & 8.9 \\
\hline C. M. & 2.15 & 0.50 & 0.45 & 3.1 & 11.9 & 15.0 \\
\hline D. W. & 3.15 & 0.17 & 0.78 & 4.1 & 9.9 & 14.0 \\
\hline \multicolumn{7}{|c|}{ B. Infectious diseases } \\
\hline B. H. & 3.06 & 1.09 & 1.55 & 5.7 & 24.6 & 30.3 \\
\hline D. N. & 1.35 & 0.23 & 0.62 & 2.2 & 2.7 & 4.9 \\
\hline N. J. & 2.56 & 0.22 & 0.62 & 3.4 & 1.2 & 4.6 \\
\hline B. C. & 1.53 & 0.15 & 0.62 & 2.3 & 4.7 & 7.0 \\
\hline D. B. & 1.13 & 0.95 & 0.28 & 2.4 & 2.1 & 4.5 \\
\hline \multirow{3}{*}{$\begin{array}{l}\text { Mean } \\
\text { Range }\end{array}$} & 1.43 & 0.30 & 0.47 & 2.2 & 6.2 & 8.4 \\
\hline & $(0.21-3.15)$ & $(0.06-1.09)$ & $(0.23-1.55)$ & $(1.2-5.7)$ & $(1.2-24.6)$ & $(4.6-30.3)$ \\
\hline & $P<0.05^{*}$ & $P<0.005$ & $P>0.10$ & $P>0.10$ & & \\
\hline
\end{tabular}

* Wilcoxon rank sum test (30). Patients are listed in the same order as in Table I.

cocci (8). In the present studies human $\mathrm{Tdr}-{ }^{8} \mathrm{H}$-labeled mononuclears rarely adhered to glass or phagocytosed particles similar in size to the bacteria. Further, human Tdr- ${ }^{8} \mathrm{H}-$ labeled mononuclears morphologically lack the immature nuclei with nucleoli and cytoplasmic basophilia characteristic of mouse promonocytes (17). Finally, Thompson and van Furth (18) reported that glucocorticoids rapidly decreased the number of circu- 
lating monocytes. In contrast, prednisolone increased the mononuclear leukocyte $\mathrm{Tdr}-{ }^{3} \mathrm{H}$ uptake in patients with inflammatory diseases. ${ }^{3}$

Thirdly, the $\mathrm{Tdr}-{ }^{3} \mathrm{H}$-labeled mononuclears may be marrow-derived precursors of promonocytes, which include pluripotent stem cells. Van Furth and Diesselhoff-Den-Dulk reported that the promonocyte probably can only divide once and must be maintained by a pool of precursor cells whose morphology is not known (19). At this time two candidates for marrow stem cells are "transitional" cell of Yoffey (20) and the "monocytoid" cell of Tyler and Everett (21). Each of these is a large mononuclear cell capable of DNA synthesis $(21,22)$ with morphological features similar to many of the circulating DNA-synthesizing cells reported in the present experiments. Stem cells have been found to circulate in the blood (23). Most recently Everett and Tyler have reported that erythroid stem cells can be recovered from experimentally induced subcutaneous exudates (24). These data are consistent with our previous suggestion that the observed DNAsynthesizing cells are marrow-derived stem cells released into the circulation in response to inflammatory stimuli (2).

Finally, it is possible that large number of tritiumlabeled macrophages were observed only because of the artificial environment in vitro. Metcalf recently described granulocytes in colonies developing from bone marrow cells which have the capacity to become macrophages (25).

The present studies emphasize the functional heterogeneity of morphologically similar "lymphocytes." Although the large $\mathrm{Tdr}^{3} \mathrm{H}$-labeled cells described resemble antigenically stimulated, recirculating, long-lived, small lymphocytes (26), the work of several investigators conclusively excludes the recirculating small lymphocyte as a significant source of macrophages (13-15). The present studies suggest that marrow-derived macrophage precursors masquerading as lymphocytes circulate in increased numbers in patients with certain inflammatory diseases. In retrospect, the work of Schooley and Berman (27) and Ginsberg and Lagunoff (28) suggests that similar macrophage precursors are present in the thoracic duct lymph as well. The presence of marrow-derived "lymphocyte-like" cells in the thoracic duct may explain the findings of Boak, Christie, Ford, and Howard who found that liver macrophages developed from thoracic duct cells (29).

The present experiments offer the possibility that the monocyte may not be the only source of macrophages in the circulation of humans. The $\mathrm{Tdr}-{ }^{8} \mathrm{H}-\mathrm{la}-$ beled large nonphagocytic cells may be very immature

${ }^{\mathbf{3}}$ Horwitz, D. A., and M. Ziff. Unpublished observations. monocyte precursors which continue to proliferate in the tissue. Increased numbers of large, nonphagocytic "lymphocyte-like" cells may reflect a "shift to the left" in the monocyte cell line, and thus, significantly increase the number of macrophage precursor cells available for recruitment to inflammatory foci.

\section{ACKNOWLEDGMENTS}

The author wishes to thank Dr. Morris Ziff for his support of this work and Dr. James G. Hirsch for reading this manuscript. Special thank are also due to Anne Russell for the photomicrographs of leukocytes.

This work was supported by U. S. Public Health Service Project grant AM-09989, Training Grant AM-05154, U. S. Public Health Service Institutional Grant FR05431-10, and National Science Foundation Institutional Grant GU 3784.

\section{REFERENCES}

1. Horwitz, D. A. 1970. Demonstration of circulating DNA synthesizing macrophage precursors in the blood of patients with inflammatory disease. Fed. Proc. 29: 826.

2. Horwitz, D. A., P. Stastny, and M. Ziff. 1970. Circulating deoxyribonucleic acid-synthesizing mononuclear leukocytes. I. Increased numbers of proliferating mononuclear leukocytes in inflammatory diseases. J. Lab. Clin. Med. 76: 391.

3. Bond, V. P., T. M. Fliedner, E. P. Cronkite, J. R. Rubini, G. Brecher, and P. K. Schock. 1959. Proliferative potential of bone marrow and blood cells studied by in vitro uptake of $\mathrm{H}^{3}$-thymidine. Acta Haematol. 21: 1 .

4. Rubini, J. R., V. P. Bond, S. Keller, T. M. Fliedner, and E. P. Cronkite. 1961. DNA synthesis in circulating blood leukocytes labeled in vitro with $\mathrm{H}^{3}$-thymidine. $J$. Lab. Clin. Med. 58: 751.

5. Wood, T. A., and E. P. Frenkel. 1967. The atypical lymphocyte. Amer. J. Med. 42: 923.

6. Cleaver, J. E. 1967. In Thymidine Metabolism and Cell Kinetics. John Wiley \& Sons, Inc., New York. 93.

7. Van Furth, R. 1970. Origin and kinetics of monocytes and macrophages. Seminars Hematol. $7: 125$.

8. Van Furth, R. 1970. In Mononuclear Phagocytes. F. A. Davis Co., New York. 3.

9. Wintrobe, M. M. 1967. In Clinical Hematology. Lea \& Febiger, Philadelphia, Pa. 6th edition. 260.

10. Frank, J. A., and T. F. Dougherty. 1958. The assessment of stress in human subjects by means of qualitative and quantitative changes of blood lymphocytes. J. Lab. Clin. Med. $42: 538$.

11. MacKinney, A. 1965. Tissue culture of cells already in DNA synthesis from patients with infectious mononucleosis. Blood. 26: 36 .

12. Volkman, A., and J. L. Gowans. 1965. The production of macrophages in the rat. Brit. J. Exp. Pathol. 46: 50.

13. Volkman, A., and J. L. Gowans. 1965. The origin of macrophages from bone marrow in the rat. Brit. J. Exp. Pathol. 46: 62.

14. Spector, W. G., M. Walter, and D. A. Willoughby. 1965. The origin of the mononuclear cells in inflammatory exudates induced by fibrinogen. J. Pathol. Bacteriol. $90: 181$. 
15. Van Furth, R., and Z. A. Cohn. 1968. The origin and kinetics of mononuclear phagocytes. J. Exp. Med. 128: 415.

16. Roser, B. 1970. The origins, kinetics, and fate of macrophage populations. J. Reticuloendothel. Soc. 8: 139.

17. Van Furth, R., J. G. Hirsch, and M. E. Fedorko. 1970. Morphology and peroxidase cytochemistry of mouse promonocytes, monocytes, and macrophages. J. Exp. Med. 132: 794.

18. Thompson, J., and R. Van Furth. 1969. The effect of glucocorticosteroids on the kinetics of mononuclear phagocytes. J. Exp. Med. 131: 429.

19. Van Furth, R., and M. C. Diesselhoff-Den-Dulk. 1970. The kinetics of promonocytes and monocytes in the bone marrow. J. Exp. Med. 132: 813.

20. Yoffey, J. M. 1960. Quantitative Cellular Hematology. Charles C. Thomas, Publisher, Springfield, Ill.

21. Tyler, R. W., and N. B. Everett. 1966. A radioautographic study of hemopoietic repopulation using irradiated parabiotic rats. Relation to the stem cell problem. Blood. 28: 873.

22. Yoffey, J. M., G. Hudson, and D. G. Osmond. 1965. The lymphocyte in guinea pig bone marrow. J. Anat. 99: 841.

23. Popp, R. A. 1960. Erythrocyte repopulation in X-irradi- ated recipients of nucleated, peripheral blood cells of normal mice. Proc. Soc. Exp. Biol. Med. 104: 722.

24. Everett, N. B., and R. W. Tyler. 1970. Erythroid repopulation of irradiated mice by mononuclear cells of subcutaneous exudates. J. Reticuloendothel. Soc. 7: 655.

25. Metcalf, D. 1971. Transformation of granulocytes to macrophages in bone marrow colonies in vitro. J. Cell Physiol. 77: 277.

26. Everett, N. B., R. W. Caffrey, and W. O. Rieke. 1964. Radioautographic studies on the effect of irradiation on long-lived lymphocytes of the rat. Radiat. Res. 21: 383.

27. Schooley, J. C., and I. Berman. 1960. Morphologic and autoradiographic observations of $\mathrm{H}^{3}$-thymidine-labeled thoracic duct lymphocytes cultured in vivo. Blood. 16: 1133.

28. Ginsberg, H., and D. Lagunoff. 1967. The in vitro differentiation of mast cells. J. Cell Biol. 35: 685.

29. Boak, J. L., G. H. Christie, W. L. Ford, and J. G. Howard. 1968. Pathways in the development of liver macrophages: alternative precursors contained in populations of lymphocytes and bone marrow cells. Proc. Roy. Soc. Ser. B. Biol. Sci. 169: 307.

30. Wilcoxon, F., and R. A. Wilcox. 1964. Some Rapid Approximate Statistical Procedures. Lederle Laboratories Div. (American Cyanamid Co.), Pearl River, N. Y. 7. 